\title{
Organic Weed Control Measures for Nigerian Cropping System
}

\author{
Joseph E.O. Ansa and Kingsley O. Wiro
}

\begin{abstract}
The need for sustainability has been the focus of every country especially developing countries of which Nigeria belongs. Population increases at an uncontrollable dimension and the provision of food for the populace becomes paramount. The productivity of crops is seriously hampered due to influence of weds which reduce the quantity and quality of plants by affecting plants growth, development and yield. Weeds reduce crops performance by as much as $80 \%$ in an uncontrolled situation. To increase crops yield and control weeds, synthetic substances like inorganic fertilizers, pesticides and herbicides were introduced into Nigerian cropping system. These off-farminputs caused soil degradation, soil compartment, soil pollution and environmental hazard as well as life uncertainty (insecurity) as herbicides enter water bodies and affect animals and human when such polluted underground water is used. Research on more efficient and effective means of saving the soil from destruction and adequate weed control measures gave rise to organic farming. The emergence of organic weed control is geared towards the effective control of weeds with environmental consideration and soil enrichment. Many organic weed control measures have been identified in Nigerian cropping system to include: use of cover crops, use of green manure, use of crop rotation, use of soil fauna, tillage, use of allelopathic plants, use of farmyard manures and biofertilizers. It was recommended that for increased food production to be achieved, organic farming system should be adopted, government at all levels should give more attention to the training of more personnel who will adequately control weeds, organic weed control measures should be advocated (encouraged) and there should be enlightenment for the Nigerian farmers on the need to adopt organic weed control measures in their cropping system for increased crop productivity.
\end{abstract}

Index Terms - cropping system, environmental enrichment, Nigeria, organic weed control.

\section{INTRODUCTION}

The need for sufficiency in food production started from the period of early man. Food is the most vital demand among all other desires or demands of man due to its role in providing the necessary ingredients required for essential metabolic processes in a living cell and by extension system. No living entity can sustain its livelihood in the absence of food. Food is regarded as the bridge between peace and anarchy because a hungry animal especially man has no limitation of what he does to explore food. Owing to the essentiality of food availability for living things, various approaches have been utilized in its realization. Reference [1] stated that no other human challenge is more critical than that of providing food for an ever-increasing human population and this has continued to be a problem such that this challenge has become more obvious in the modern days due to population explosion.

Published on November 21, 2020

J. E. O. Ansa, Department of Agriculture, Ignatius Ajuru University of Education, Nigeria.

(email: joseph.ansa ${ }^{@}$ iaue.edu.ng)
Increased food production was generated from cultivating more land in traditional setting but in large areas of the world like Asia all the land that could be economically cultivated has already been used [2]. It therefore means that in future, for the teaming population to survive, the extra food required must be produced from higher production from land that have already been farmed. A huge proportion of this expected food increase is likely to come from increasing the number of crops produced per year on a given land using improved crop varieties and use of other modern farming techniques to achieve improved production. In Rivers State it was observed that most horticultural farmers utilize uncertified seeds in their cultivating, which prompted advocacy for the use of certified seeds to boost crop productivity [3]. Multiple cropping is one of the many systems utilized which offers potential not only to increase food production but also land degradation. The capacity of crops production is affected by the type of cropping system used [4].

\section{OBJECTIVE OF THE PAPER}

The need for adequate food provision to every country is a mandatory function of every government to prevent food shortage that will cause anarchy. But adequate production of food is greatly influenced by weed interference which significantly lowers crop growth and yield. Before now, the use of herbicides was advocated for weed control, but herbicides posed several problems to the plants, soil, environment and man, thereby giving room for a more reliable measures of weed control.

The aim of this paper is to:

1. determine more effective measures of weed control in Nigerian cropping system.

2. determine the effectiveness of organic weed control measures in Nigerian cropping system for crop production.

\section{Meaning Of Organic Agriculture}

The concept "Agriculture" involves the production of livestock and crops for the consumption of man. Organic agriculture describes the type of agricultural operations whereby no chemical compounds are used during production. Organic materials from animal such as animal dung, poultry, and pig manure as well as materials from plants such as mulches etc. are used instead of fertilizers and herbicides for soil amendment and weed control.

Composed of legumes, grasses and other broadleaf species, pastures provide multiple benefits for the soil and ecosystem.

K. O. Wiro, Department of Agriculture, Ignatius Ajuru University of Education, Nigeria.

(email: kingsco2018@gmail.com) 
The fibrous roots of the grasses in perennial pastures hold soils in place and help reduced soil erosion. When the roots and stubble of the grazed grass die, they contribute organic matter to the soil. These improvements in organic matter from the gasses, as well as the legumes help improve soil water infiltration, soil texture and structure, soil aeration and nutrient accumulation and storage. Pastures of elephant grass help to prevent soil erosion by holding the soil particles together [5]. Organic farming is a new science innovation and technology in the farming business. Designing an organic farming system to tie together principles of sustainability and productivity is complex. Organic farmers must consider how the various components of their system such as rotation, pest and weed management and soil health will maintain both productivity and profitability.

\section{ORIGIN AND CONCEPT OF ORGANIC FARMING}

The term 'Organic Farming' came into existence in the nineteenth century (1905-1927) by a British botanist named Albert Howard in the central Europe and India. Sir Albert Howard is referred to as the father of modern organic farming. Sir Albert Howard was an agricultural adviser in Pusa, Bengal (now in Bihar). In a demonstration farm, he discovered the superiority of organic farming over the traditional Indian farming practices. Rodale, J.I. also added his weight in the popularization of organic farming and methods of organic farming [6], [7].

Lord North Bourne in 1939 formally used the concept "Organic Farming". He described farm as an organism and expended this concept more in his book "Look to the Land" in 1940. Lady Eve Balfour complemented the work as she scientifically compared the productivity potential of conventional and organic farming. Before the advent of organic farming as a system of modern farming, agricultural activities had been in place since the period of early man devoid of the addition of off-farm inputs like synthesized fertilizer to add plant growth, development and yield, pesticides and herbicides to control weeds. But as the population increased astronomically, there was the need to produce fertilizer to increase crop production. These synthetic fertilizers and herbicides were unfriendly to the ecosystem, environment, animals and even human as they posed some inherent dangers such as soil compaction, soil erosion, reduction in soil fertility, causing water pollution, raising health concerns as the toxic chemical entered the food and water thereby causing food poisoning [7]. These negative effects of off-farm inputs gave room for research on the best form of farming system that would be health amendment, environmentally and soil friendly.

It is a farming system that relies mostly on the use of material devoid of chemical substances like synthetic fertilizer, herbicides, pesticides, etc. but employs the use of organic materials in the farming operations, such as crop rotation, farm yard manure, crop residues, mulching, green manure and cover cropping, off farm waste and aspect of biological pest control to maintain soil productivity and tilt to supply nutrient and to control insects weed and other pests are utilized to carryout crop production and improve soil structure, texture and silt, to supply the essential soft nutrients
[8]. Most farmers practice traditional (sustainable) agriculture with the aid of materials from organic origin such as poultry manure, pig manure, plant residues, mulching materials, goat dung, camel dung, cow dung, rabbit dung, palm bunch ash, etc. but the practice of organic farming especially certified (organized) is still a new innovation in Nigeria.

Organic manure is the main source of fertilizer in this farming system. The use of organic manure has been advocated for a long-time. Cropping activity in the tropical region has slow mineralization of these manures required to promote high crop productivity for a long time [9]. Poultry manure produces huge yield relative to goat and dry cow manure and helps to change the chemical and physical characteristics of the soil and helps in the rubber crops which is a noticeable cash crop of many growing economies [10]. Organic farming endorses the concept that plants and animals are linked. Its goal is to create an integrated environmentally healthy, safe, and economically sustainable agricultural production system [11].

A major feature of organic farming is the primary dependence on site-specific natural resource and those developed locally (green manures, crop residues, farm wastes, etc.) rather than external inputs (such as synthetic products, like fertilizers, herbicides, additives for crop production). The farmer manages self-regulating ecological and biological processes for a progressive sustainable and economic cropping system in the production in farming operation. It is of important note that organic farming is a production system which avoids or greatly excludes the use of synthetic inorganic fertilizers, pesticides, etc. Organic farming systems largely depends on crop rotations, crop residues, animal manures, green manures, off-farm organic waste, mechanical cultivation, mineral bearing rocks and aspects of biological pest control to maintain soil performance, to supply plant macro and micro nutrients and to control weeds [12]. Organic farming does not use toxic agricultural inputs but are based on development of biological diversity and the maintenance and replenishment of soil for enhanced productivity.

Organic farming is therefore a farming system that whereby the land, plants, animals, and human beings are linked. In philosophical description, organic farming means farming in agreement of organic relationship [13]. It is farming system advocated for soil improvement, high crop production, environmentally stable status, and more purified ecosystem. Organic farms are aimed at producing an integrated, environmentally sound, safe, economically, and ecologically sustainable agricultural production method.

\section{COnCEPT OF Sustainability}

The food production scenario is beset with ecological, technological, and demographic problems. In contrast, the demand scenario features a high growth rate in food grain requirements. Such a situation will lead to dwindling global food reserves and an escalation in the cost of food grains and other agricultural commodities. Reference [14] stated that the need for redoubling our efforts in enhancing agricultural production and in promoting agrarian prosperity is obvious. Fortunately, there is growing interest in promoting sustainable agriculture which is also referred to by other names such as 
alternate farming, regenerative agriculture, natural or organic farming ecofarming, permaculture, etc.

Sustainable agriculture is a broad concept that covers several different approaches all function in one way or other to achieve environmentally sound, economically, ethically acceptable, and socially responsible form of land husbandry. They have much in common with each other and different people and organization define them differently, so overlap is not unusual.

The concept of sustainable agriculture has been conceived differently by different authorities/authors. In economic terms, the use of resources today should not reduce real incomes in the future. Sustainable development has been defined as improving the quality of human life while living within the carrying capacity of supporting ecosystems [15]. It is a sustained development as development that meets the needs of the present without compromising the ability of the future generations to meet their own needs.

In essence, sustainable development means protecting the natural resources needed for food grain production and cooking fuels, while expanding production to meet the needs of growing population. In other words, sustainable development means more efficient use of arable lands and water supplies as well as development and adoption of improved agricultural practices and technologies to increase crop yield.

\section{Sustainability In Agriculture}

Organic farming is one of the methods (techniques) used for sustainable agriculture and many of the techniques used include intercropping, addition of poultry manure and other animal manures, crop rotation, ploughing, mulching, integration of crops and livestock, etc. What makes organic farming unique is that almost all synthetic inputs are avoided and soil health improving agronomic practices are maintained. The addition of poultry manure improved the soil structure, added nutrients to the soil and thus increased crop productivity [16]. Sharma and Rajput [17] stated that Organic farming is the pathway that leads us to live in harmony with nature. Organic agriculture is the key to health development and a sustainable environment. It drastically reduces environmental pollution and the use of non-conventional natural resources. It conserves soil fertility and soil erosion through implementation of appropriate conservation techniques.

There is the urgent need for agriculture to be sustained because there must have to be food for the over-increasing population of the world. Organic agriculture is production management system, which promotes, encourages, and enhances agro-ecosystem health, including biodiversity, biological cycles and soil biological activity. It emphasizes the use of management practices in preference to the use of off-farm inputs, taking into consideration that regional conditions require locally adopted systems.

\section{NEED FOR ORGANIC FARMING}

Organic farming is geared towards high crop production. Organic farming systems are based on the dynamic interaction between the soil, plants, animals, human beings, ecosystems and the environment. The system is directed towards promoting natural practices involved in all the production strategies. There are many reasons for organic farming to be sustained. Reference [18] identified the reasons for organic farming to include the following:

1. Reduced land holdings.

2. Poor economic condition of the farmers.

3. Rise in inputs costs.

4. Ever increasing population.

5. Demanding increased food production.

6. Depletion of natural resource base and environmental pollution stresses the need for ceo-harmonious technologies.

7. To produce food of high nutritional quality in sufficient quantity.

8. To promote, encourage and enhance biological cycles within the farming system, involving microorganism, soil flora and fauna, plants, and animals.

9. To maintain and increase the nutrient capacity of soil

10. To use as renewable resources in locally organizing agricultural systems.

11. To work within a closed system with regard to organic matter and nutrient elements.

12. To avoid all forms of pollution that may result from agricultural processes, practice and techniques.

13. To put into consideration the wider social and ecological impact of the farming system.

14. To allow agricultural producers enough return on their investment and satisfaction in their farm activities including a safe working environment. The quality and quantity of farmers production and the money realized from their farming business is a strong zeal to retain in the business [5].

15. To maintain the genetic diversity of the agricultural system and its surroundings.

\section{WEEDS AND NEED For WeEd CONTROL}

Weeds are defined in different ways by different authors [19]. Reference [20] defined weeds as global enemies to the goals, interests and activities of man which destroys crop production systems and disrupt industrial and commercial processes. Weeds are plants, whose description is best determined by the farmer. They are plants of diverse complicity in management and control. Weeds are plants whose obnoxiousity is determined by the farmer at any given time depending on the prevailing circumstances. Weeds are the major problem of crop production in the world [21], [22]. They can survive many generations and compete with plants for nutrients in the soil, space, sunlight, and water. Weeds reduce farmers disposal income by adding to crop cultivation practices (in weeding), which force some farmers out of business as platable crop production and reasonable income generation will encourage more farmers to remain in farming activities [5]. Weeds reduce the growth, development, and yield of crops substantially [21]. Weeds are plants considered to be worthless to the farmers but could serve critical purpose 
at certain situations. Elephant grass, one of the notorious weeds could be cultivated to produce nutritive pasture for the animals and ethanol for human consumption [23]. Weeds cause remarkable reduction in the yield of the crop between $75 \%$ and $87 \%$ as compared with those kept free from weeds within the growth period. Weeds have been known to be a major menace to the vegetative growth yield of crops from the era of early man till date [24]. Farmers are greatly faced with the problem of weed management while carrying out farming activities and the interference of these weeds in the growth, development, and productivity of crop plants. Farmers are concerned with the effects of weeds in the overall performance of the vegetative growth and yield of crops [25]. The desires for more efficient and effective measures of weed control had led to several research been carried out with a view to increasing crop production. One of such numerous research gave rise to organic farming. Organic farming among numerous advantages, helps in weed control [26].

Unfortunately, there are very few professionally trained people to carry out the needed research in weeds and their control [19]. He added that there is the urgent pressing need for professionally trained weed scientists in the tropics to join in weed scientific research at levels of importance that will really promote, enhance and advance weed control beyond the art of pulling out weeds to the scientific standard where knowledge and operations are produced so as to improve on existing technologies and techniques and to invent new innovations with which the menace of weeds on crops will be minimized. Agricultural pests include insects, mites, nematodes, plant pathogens, vertebrate pests and weeds. They have lived with humans as components of the natural system since the dawn of civilization.

In natural systems the physical, chemical, and biological forces are in a dynamic but fairly well-balanced state [27]. Humans in an attempt to increase food production are constantly trying to change these forces by threatening the food supply of the other organisms and forcing them into competition with humans for increasingly reducing natural resources.

Weeds are the most underestimated pests in tropical agriculture [28]. They have greatly influenced human social, biological and economic actions more than other crop pests. The widespread refusal of governments of developing countries of the world to recognize weeds as major crop pest has been greatly responsible for the lack of trained weed science personnel to research on how to develop and improve effective weed control practices. This has continued to make weeds to take up more of the farmers time, energy, and resources than any other crop production inputs.

\section{Organic Agricultural Methods In WeEd CONTROL}

Organic agricultural methods on weed control involves the use of weed management methods devoid of synthetic substances like herbicides. It considers integrated weed control measures (IWCM) which requires multiple tactics of weed management for weed population below economic injury level and conservation of environmental quality. A successful integrated weed control measures had the principle of enhancing and encouraging farmer's productivity, environmental protection, and responsiveness to consumer preference. Integrated weed control promotes agricultural production [29]. Major components of integrated weed control measures include:

1) Low cost agronomic strategy for weed management.

2) Emphasis on ecological, biological, and biotechnological managements for environmental safety and

3) Monitory weeds, shifts in weed flora, appearance of resistant weeds and introduction of new weeds.

\section{Weed Control Measures In Organic Farming In NIGERIAN CROPPING SYSTEM}

Weed control is one of the usefulness of Organic farming. Organic Farming Weed Management Strategy (OFWMS) adopts weed suppression mechanism which promotes, enhances, and encourages crop competition and phytotoxic influence on weed [26]. Weed control measures in organic farming is devoid of the use of synthesized chemicals that are used to control weeds in conventional farming. The technology of organic weed control in farming considers selection of competitive crop varieties, higher density planting, close plant spacing. Late planting are some ways to enhance competitiveness and reduce immensely the effect of weeds on the cultivated crops during cropping season. Weeding techniques involves mechanical and physical approaches and can be classified as tillage, mowing, and cutting, flame weeding, thermal weeding and mulching [30].

Organic agricultural management of weeds control include use of cover crops, use of green manure, crop rotation, use of mulch, application of animal faeces, use of allelopathic plants [31].

\section{A. Use of Cover Crops}

The use of cover crops helps to provide fertility, control weeds and provide habitat for beneficial insects. It has a diversity of plant species to encourage natural predator, discourage pest and disease build up, and minimize economic and environmental risk. The use of cover crops also helps to provide a balance between soil conservation and crop production by adding organic matter to the soil to both supply nutrients and improve soil quality properties such as water infiltration and water holding capacity. It provides weed control by alternating between warm and cool weather plants. Close spacing of the cultivated crops prevents the emergence of weeds. The influence of spacing on growth and yield of cultivated crops is great [32]. Spacing provides the crop the available surrounding soil volume for exploration and the above ground aerial environment for the formation of canopy for proper use of aerial resources such as air and sunlight. Close spacing discourages the emergence and interference of weeds.

Use of cover is a major practice of improving soil fertility. They put to effective use natural resources in above-andbelow ground biodiversity [33]. Use of cover crops also makes it possible for the inhabitation if different species of ground-nest bride, small mammals as well as nectar and pollen sources for various kinds of insects thereby providing a physical temporary living place for the mentioned organisms which contribute in one way or the other in enriching the soil fertility. Cover crops in addition to its 
usefulness, helps to solve the problem of water infiltration, soil [34].

\section{B. Use of Green Manure}

The utilization of green manure prevents the growth of weeds as the underneath weed species are hindered from direct contact with sun and air. Soil improvement and amendment can be achieved using green manure. Suppressing of weeds and compaction are often considered when selecting green maturing to better the status of the soil for a better crop performance. When live plants in the field are ploughed into the soil and allow to decay to add to soil fertility, the process is green manuring. The decomposition of these plants kills weed seeds and underground weeds thereby preventing the germination of weeds, thus serving as an organically weed control measure in the cropping systems in Nigeria. Green manure can add to the soil nitrogen by $10-60 \mathrm{~kg}$ per hectare per year to the incoming crop to increase soil nutrient capacity [35]. Green manure increased sunflower yield by $310 \mathrm{~kg} \mathrm{ha}^{-1}$ by adding over $50 \% \mathrm{~N} \mathrm{ha}^{-1}[36]$.

\section{Use of Crop Rotation}

Proper use of crop rotation programme helps to control weeds. Corp rotation is a vital organic farming system. It provides organic matter (the legumes added to it) amends the soil. These amendments not only feed the plants but the soil organisms as well. As soil organic matter accumulates, soil structure improves and population of other important soil organisms such as earthworms which tunnel through the soil, improving aeration and infiltration increases. These organisms break down organic materials to release nutrients at a steady face, so they are available for plant uptake. Soil microorganisms also hold nutrients in a more stable form, so they are less susceptible to being lost-through leaching, soil erosion or run off. These activities inhibit the growth of weed species thereby check the growth of weeds.

Crop rotation provides above and below ground living place for emerging crops which has district chemical and biological composition, introducing new plants to the area thereby increasing crop residue to the edaphic environment [37]. Crops have different residue which can either promote or discourage the survival of pests and disease by breaking the continuous presence of a crop host. Crop rotation as an organic weed control measure in Nigerian cropping system helps to short circuit the accumulation of weeds, insects and diseases thereby removing the use of off-farm inputs such as herbicides.

\section{Use of Soil Fauna}

Researchers have stated that weeds can be controlled by the use of certain microorganisms. The study of the role of bacteria, nematodes and other soil organisms that help to make nitrogen available to plants. The synthesis of nitrogen by these soil microorganisms involve constant turning (chopping of the soil particles) which prevent growth of weeds. Earthworms, terminates and other pests in their activities in the soil continually turn the soil particles for proper soil infiltration, aeration and adequate heating by the sun. This processes expose weed seeds thus acting as organically weed control measure.

\section{E. Tillage}

This involves the turning of the soil which exposes weed roots as the roots of the weeds are mixed with the soil. This method is remarkably effective in organic weed control.

Ploughing (Turning up of the soil) bring about unfavourable condition for multiplication of pests as well as diseases and weeds.

Quiescent stages (pupae) of harmful organisms that live in the soil are exposed to dehydration or to predation by birds and other stages may be mechanically damaged or buried deep in the soil [38].

Thus, practices suppress the growth of weeds thus performing an efficient measure of controlling weeds organically.

\section{F. Use of Allelopathic Plants}

Allelopathy explains the secretion of chemicals by certain plants to inhibit or kill other plants. Weeds are pant. Modernly, some plants are grown to check the growth of other plants thus acting as a method of weed control etc. Some plants with allelopathic include English Laurel (prunus laurecerasus), Bearberry (Arctostaphylos uva-ursi), Sumac (Rhus), Elderberry (Sambucus), Holdenrod (Solidago) etc. Trees are great examples of allelopathic in plants. For example, many trees use allelopathic to protect their space by using their roots to pull more water from the soil such that other plants cannot survive. They use their allelochemicals to inhibit germination or prevent development of nearby plants [39]. Most allelopathic trees exclude chemicals substances through their leaves which are harmful when absorbed by other plants. Black walnut store allelochemical in its leaves, buds, nut hall and roots. The chemical responsible for its toxicity is known as juglone. This substance remains in the soil around the tree and is most potent at the drip line though the roots can spread out well beyond. Crops must be susceptible to the black walnut's toxicity include pines, birch trees, nightshade plants like tomatoes, peppers, eggplants, potatoes, a zaleas etc.

This explains why the surrounding of some tree plants are free of weeds. Thus, use of allelopathic plants could be used as an organic measure for weed control in Nigerian cropping system especially in plantation cropping.

\section{G. Farmyard Manure}

The use of farmyard manure makes the soil unconducive for the growth of weeds. Farmyard manure helps to increase the fertility of the soil thus increasing crop production [6]. The addition of animal's waste is another measure of weed control in organic farming. The animal waste when added in the soil pass through the process of decomposition which destroys weed seeds that are buried in the soil, this therefore suppresses the growth of weeds. The use of compost/farmyard manure make the soil unconductive for the growth of weeds.

\section{H. Biofertilizers}

Soil microbes play a vital in transformation of nutrients for plant use. Biological soil fertility management is an ecological approach for sustainable crop production. These micro-organisms are inoculated by using biofertilizers in soils that lack them. Biofertilizers are products containing living cells of micro-organisms that have the capacity to mobilize nutrients from nonusable form through biological processes. 
A plant injected with Aozspirillum promotes the uptake of potassium, Nitrate and $\mathrm{H}_{2} \mathrm{PO}_{4}^{-}$and releases various metabolites such as Cytokines, riboflavin and vitamins causing higher growth and development in various legume and non-leguminous plants [30], [40].

Estimates made on global statistics indicates that Rhizobia (legume association) cyanobacteria and Azospirillus (grases association) can fix nitrogen in the range of 30 to 280,13 to 30 and 20 to $35 \mathrm{~kg} \mathrm{ha}^{-1}$ per year. Azospirillum, rhizobium and phosphobacteria promote plant growth and development to producing growth regulators, facilitating nutrients uptake, increasing mineralization, reducing plant trees and lodging, stimulating root nodulation, and promoting nitrogen fixation in the soil [41].

The activities of these micro-organisms expose the weed seeds which were laid underground to the surface and are dried by the sum thereby suppressing and inhibiting the growth of weeds. Thus, biofertilizer are important for nutrient fixation in the soil and organic weed control measure in Nigerian cropping system.

\section{Summary AND CONClusion}

Weeds which have been described as enemies of plants and farmers have over the years caused a serious damage to crop by influencing plants growth, development, and yields.

A deliberate attempt to reduce and control weeds has led to the adoption of a new farming system which is devoid of synthetic substance called organic farming. Organic farming is aimed at improving the soil nutrient status as well as controlling weeds in Nigerian cropping system. Some of the organic weed control measures include the use of cover crops, use of green manure, use of crop rotation, use of soil fauna, tillage, use of allelopathic plant, use of farmyard manure and bio-fertilizer. Organic farming will help in providing more food for the ever-increasing population and to amend soil which has been degraded. It will also act as the most environmentally and economically means of weed control.

\section{RECOMMENDATION}

Having examined the importance of organic weed control measures in Nigerian cropping system, it is recommended that government at all levels should give attention to the training of more personnel's to adequately control weeds. Again, the use of organic weed control measures should be advocated (encouraged) in Nigerian cropping system and finally, there should be enlightenment for the Nigerian farmers on the need to adopt organic weed control measures which is geared towards improving soil fertility, elimination of soil degradation and environmental pollution and provision of healthy farm produce for man and his animals as well as efficient control of weeds, in Nigerian cropping system.

\section{REFERENCES}

[1] Singh, N.B and Verma, K.K (1998). Production Potential and Economic analysis ofrice-based cropping systems. Indian journal of agronomy 43:199-203.

[2] Willey, R.W and Osiru, DSO (2000). Studies on mixtures of maize and beans with particular referenced to plant population. Journal of Agricultural Sciences, Cambridge 79:519-529.

[3] Wiro, K.O. (2020). Assessing the level of utilization of certified seeds by Horticultural Farmers in Rivers State. International Journal of Education Humanities and multidisciplinary Research. 10(1):108-116.

[4] Ansa, J.E.O and Wiro, K.O (2018). Potential of Taungya System for sustainable livelihoods Nigeria. Science and Industrial Technology Education Journal 6(1): 28-38.

[5] Wiro, K.O. and Ansa, J.E.O. (2019). Socio-economic potential of taungya farming for sustainable food production in Nigeria. International Journal of Interdisciplinary Research Innovations 7(4): 13-21.

[6] Finamore, A., Britti, M.S., Roselli, M, Bellovina, D., Graetani, S and Mengheri, E. (2004). Novel Aproach for food safety evaluation. Results of a pilot experiment to evaluate organic and conventional foods. Journal of Agriculture and food chemistry 52:7425-7431.

[7] Stinner, D.H (2007). "The Science of organic farming" In William Lockeretz (ed). Organic farming: An International History. Oxford shire, UK and Cambridge, Massachusetts.

[8] Patidar, S. (2015). A study of perception of farmers towards organic farming. International Journal of Application innovation in Engineering and Management (IJAIEM) 4(3):269-277.

[9] Gambo, B.A., Magiji, M.D., Yakubu, AL. and Dikko, A.U. (2008). Effects of-farm yard manure and weed interference on the growth and yield of onion (Ailuim cepa). Journal of sustainable Agriculture and Environment; 3(2): 87-92.

[10] Clark, A. (2001). Effect of planting dates and intra row spacing on the performance of two cultivar of sweet potato. Boston L.C. page and Co. 88-102.

[11] Makinde, E.Q.A., Ayemi, L.S., Ojeniyi, S.O. and Odedina, T.N. (2010). Effect of organic, organic-mineral and NPK fertilizer on nutritional quality of Amaranthus in Lagos, Nigeria. Researchers. 2(2):91-96.

[12] Muller, Z.0. (2004). Feed animal from animal waste: Feeding manual. FAO Animal production and health paper 28:214. http//catalogue.nla.gov .au/record/23 51034.

[13] Tuck, S.l., Wingrist, C and Mota, F (2014). Land use intensity and the effects of organic farming on biodiversity: a hierarchy and metaanalysis Journal of Applied Ecology 5 (1):746-755.

[14] Tarhalker, P.P. and Rao, N.G.P. (1995). Changing concepts of practices of cropping systems. Indian Farming 25:3-7.

[15] Trenbath. BR. (1996). Resource use by intercrops in Francis, C.A (eds) multiple cropping systems. Macmillan publishing company, New York.

[16] Adesina, O. L. and Wiro, K.O (2020). Influence of poultry manure rates on the growth and yield of Okra (Abelmoschus esculentus (L) Moench) in Rivers State. Journal of Experimental Agriculture International 42 (1): 116-120.

[17] Sharma, BR. and Rajput, A.L. (2005). Sustained rice production in Eastern India through efficient waste management techniques. Indian Journal of Agronomy 35:85-90.

[18] Tiripathi, S.S., Vivex, C. and Dhyani, B.P. (1998). Economics and nutrient harvest in sequential cropping systems. Indian Journal of Agronomy 43:248-252.

[19] Akobundu, 1.0. (1987). Weed science in the tropics, principles and practice. John Willey and Sons Inter-Science Publication. New York 103.

[20] Ansa, J. E. O and Iyagba, A. G. (1999). Elements of Tropical Crop Husbandary. Obchikel publishers, 17/19 Emenike street, mile 1 Diobu, Port Harcourt, Rivers State. 89-99.

[21] Adejonwo, K.O., Ahmed, M.K., Lagoke, S.T.0. and' Karikari, S.K. (2009). Effects of variety nitrogen and period of weed interference on growth and yield of okra (Abelmoschus esculeptus). Nigerian Journal of Weed Science, 2:21-27.

[22] Wiro, K.O. and Iyagba, A.G. (2020). Effect of Weeding Regime on the Performance of Cucumber (Cucumus sativus) In the South-South Rainforest of Nigeria. American Journal of Multidisciplinary Research \& Development (AJMRD) Volume 2, Issue 7 (July-2020), PP 34 38ISSN: 2360-821X www.ajmrd.com.

[23] Ansa, J.E.O, Wiro, K.O and Garjila, Y.A. (2019). Potential of laterite soil for the production of elephant grass (pennisetum purpureum) in Nigeria. International Journal of Life Science Research. 7(4):1-4. 
[24] Stall. WJvl. (2011). Weed control update for cucurbits crops (Muskmelon, cucumber, squash and watermelon) (online). Available at http://eclis.ifas.uf1.edu/wgo29 (verified 18 July, 2011).

[25] Noble, 0. (2011). Working towards better cucubits weed management strategies for the coming season (ontime) available at http://www.growingmagazine.com/fruits/working towardsbettercucurbit (verified 18 July, 2011).

[26] Delate, Kathleen, "Weed Management for Organic Farmers" (2003).Extension and Outreach Publications. 53.http://lib.dr.iastate.edu/extension_pubs/5.

[27] Aldrich, R.J. (2004). Weed crop ecology: principles in weed management. Breton Publishers, North Scituate, MA, 465.

[28] Ogg, A.G., and Dawson, J.H. (1984). Time of emergence of eight weed species. Weed Science 32: 327-335.

[29] Hosmani. M.M. \& Maitis, S.S. (1993). Non chemical means of weed management in crop production. In: proceedings of the symposium on integrated weed management for sustainable agriculture. Indian Society of Weed Science, Hissar, India

[30] Hatcher, P.E. and Melander, B. (2003) Combining physical, cultural and biological methods: prospects for integrated non-chemical weed management strategies._Weed Research, 43 (5). pp. 303-322. ISSN 0043-1737 doi: https://doi.org/10.1046/j.1365-3180.2003.00352.x.

[31] Gliessman. S.R. (1983). Allelopathic interactions in crop/weed mixtures: Application for weed management. Journal of Chemical Ecology 9:991-999.

[32] Effa, E.B., Uko, A.E., Undie, U.L and Ansa, J.E.O (2018). Intra-Row spacing and variety interaction effects on the yield performance of sunflower (Helianthus annuus. L) in Calabar. Journal of Agricultural studies. 6(2):133-144.

[33] Tyler, D.D., Wagger, M.G., McCracken, D.V., Hargrove, W.L and Carter, M.R (2014). Role of conservation tillage in sustainable agriculture in the Southern United States, Conservation in tillage in temperate grocesystems. Lewis publications incorated, Boca Raton, 209-229.

[34] Burgos, N.R and Talbert, R.E (1996). Weed control by spring cover crops and imazethapus in no-till Southern Pea (Vigina unguiculata). Weed Technology 10:893-899.

[35] Amanullah, M.M., Somasundaram, E., Sathyamoorthic, K and Thukkaiyanman, P (2008). Organic farming in relation to food and environmental security a review, green farming 1(10):5-10.

[36] Bahi, G.S and Pasricha, N.S (2001). Direct and residual effect of green manuring in relation to fertilizer nitrogen on Toria (Brassica napus (L)) and sunflower (Halianthus annuus (L)) Journal of Indian Society of soil Science 49(1):113-117.

[37] Roberson, E.B; Sarig, S. and Firestonck, M.K (1991). Cover crop management of polysaccharide mediated aggregation in an orchard soil. Soil Science Society American Journal, 55:734-739.

[38] Altieri, M.A and Liebman, M. (2006). Insect weed and plant disease management in multiple cropping system. In: Francis C.A (eds) multiple cropping systems. Macmilliam publishing Company, New York.

[39] Zhang, Y. H (2010). Induced effects of exogenous phenolic acids on allelopathy of a wild rice accession (oryza congistaminata). Rice Science 17:135-140.

[40] Saubidet,M.I., Fatta, N and Barneix, A.J (2000). The effects of inoculation with Azospirillum brasilense on growth and nitrogen utilization by wheat plants. Plant soil 243 (2). 215-222.

[41] Remans, R., Spaepen, S. and Vanderleyden, J (2006). Auxin signaling in plant defense. Plant science 313:171-179.

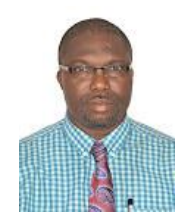

\section{Joseph E.O. Ansa Ph.D}

Department of Agriculture (Agronomy Unit), Ignatius Ajuru University of Education, Port Harcourt, Rivers State, Nigeria. Though born in Lagos, in May, 1965, Dr. J.E.O. Ansa obtained the Bachelor of Science in Agriculture (Crop Science) and Master of Science in Agronomy (Crop Science) from the University of Ibadan, Nigeria and a doctorate in Crop Production from the University of Calabar, Nigeria.

His major field of study and research interest is in Agronomy, Crop nutrition, Eco-physiology, and Farming Systems. He has been teaching higher education courses such as crop physiology, pasture and forage crops production, arable crop production, agroclimatology, cropping systems and statistical research.

Dr. Ansa has published and coauthored several journal articles and books, supervised $\mathrm{PhD}, \mathrm{MSc}$ and BSc projects. His current research interest is in iodine biofortification of crops and the effects of planting density and fertilizers on sunflower production in tropical rainforest.

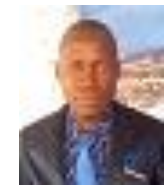

\section{Kingsley O. Wiro MSc}

Kingsley O. Wiro, a native of Emuoha, Local Government Area authority, Rivers State hold the Bachelor's degree in Agricultural Education, University of Ibadan, Nigeria and the Master of Science degree in Agronomy, Ignatius Ajuru University of Education, Port Harcourt, Nigeria. He is presently a doctoral student in Crop Production at Ignatius Ajuru University of Education, Port Harcourt. Nigeria. His research interest is in organic crop production, weed science and sustainable agricultural production and livelihood

Mr. Wiro has published several referable articles in both local and international journals. He is a devout Christian and is happily married with children 